Estudios Constitucionales, Año 8, No 2, 2010, pp. 675 - 706.

ISSN 0718-0195

Centro de Estudios Constitucionales de Chile Universidad de Talca

"A paradoxal face 'hipermoderna' do processo constitucional:

Um olhar sobre o direito processual brasileiro"

Jânia Maria Lopes Saldanha

\title{
A PARADOXAL FACE "HIPERMODERNA" DO PROCESSO CONSTITUCIONAL: UM OLHAR SOBRE O DIREITO PROCESSUAL BRASILEIRO
}

\author{
JÂNia Maria Lopes Saldanha ${ }^{1}$ \\ "Isso de querer ser exatamente aquilo que a gente é ainda vai nos levar além".
}

Paulo Leminski

RESUMO: Análise da relação entre pós-modernidade, neoliberalismo e hipermodernidade e a consequência sobre as reformas processuais brasileiras que estabelecem a celeridade e a quantificação como os metavalores da jurisdição.

ABSTRACT: Analysis of the relationship between post-modernity, neoliberalism and hypermodernity and the consequence on the Brazilian processual reforms that establish the celerity and the quantification as the meta-values of the jurisdiction.

Palavras-Chave: Jurisdição. Processo. Neoliberalismo. Hipermodernidade. Quantificação.

KEY WORDS: Jurisdiction. Process. Neoliberalism. Hypermodernity. Quantification.

Sumário: Introdução; Parte 1 A relação circular entre Pós-modernidade, neoliberalismo e hipermodernidade: A propósito de uma Jurisdição modelada; Parte 2 Crônica de uma morte anunciada: As reformas que prestigiam a quantidade e desprezam a qualidade em um processo neoliberal; Consideraçôes Finais; Referências.

\section{INTRODUÇĀO}

No momento em que este artigo é escrito, encontra-se em curso no Brasil o projeto de criação de um novo Código de Processo Civil. Parte dos homens ainda

\footnotetext{
${ }^{1}$ Doutora em Direito da Universidade do Vale do Rio dos Sinos - São Leopoldo, RS, Brasil. Professora dos Cursos de Mestrado, Doutorado e Graduação em Direito da mesma Universidade. Professora do Curso de Direito da Universidade Federal de Santa Maria - Santa Maria, RS, Brasil. Este trabalho é produção parcial do projeto desenvolvido sob os auspícios do CNPq, coordenado pela autora e intitulado "Entre o neoliberalismo e a democratização: Os relatórios do Banco Mundial e os (im)pactos para a reforma do Poder Judiciário brasileiro confrontados ao imperativo da desfuncionalidade estrutural" desenvolvido em rede por meio da atuação de pesquisadores de várias universidades, dentre elas a UNISINOS e a UFSM. E-mail: janiasaldanha@gmail.com
} 
deposita valor no Direito e na sua codificação para reger a vida em sociedade e para assim minimamente "socializar" a insociável sociabilidade humana de que já falara Kant. Entretanto, não se trata mais de pensar o Direito apenas como expressão da vontade soberana dos Estados Nacionais. O mundo mudou.

Marcado por inumeráveis avatares, especialmente pelas duas grandes guerras, o cenário internacional a partir da segunda metade do Século XX foi paulatinamente ganhando cores múltiplas como expressão de abertura ao diálogo e no âmbito dos Estados a vinculação entre Constituições que assegurassem direitos fundamentais e democracia foi inexorável. Dentre eles o acesso à Justiça que aqui deve ser compreendido como todo aquele que garante o devido processo legal, a ampla defesa, o contraditório e a fundamentação das decisões. Assim, a vigilância permanente e efetiva desse princípio transcende às jurisdiçōes dos Estados e ganha fóruns internacionais a exigir uma mudança paradigmática do jurista para reconhecer no processo um direito constitucional fundamental que deve estar alinhado ao direito internacional. A relatividade histórica dos conceitos, como já lembrara Calamandrei, implica na necessária refundação da concepção de processo e jurisdição, dois pilares importantes do direito processual.

Entretanto, a maioria dos códigos de direito processual de países de tradição civil como a do Brasil foi elaborada sobre as bases do direito romano canônico e num tempo de menor complexidade das relaçóes jurídicas, da troca de comunicação e de informação. Assim, a tão falada crise do processo e da jurisdição não nasceu no vazio, mas sim em um contexto histórico em que novos direitos foram surgindo em decorrência de fatores culturais, econômicos, políticos e sociais que, somados, produziram novas categorias de demandas para as quais as estruturas processuais não podiam dar resposta satisfatória.

A emergência e o descumprimento dos direitos humanos de segunda, terceira e quarta geraçóes que surgiram no contexto do Estado Social e do Estado Democrático de Direito, forjaram paulatinamente uma reforma funcional dos sistemas processuais. Às novas categorias de direito material, agora para além das esferas privadas e individuais das pessoas, era necessário corresponder, no plano das demandas em Justiça, processo com procedimento adequado à sua satisfação do ponto de vista da hermenêutica constitucional do acesso à Justiça. Mas há de perquirir-se se essas experiências de reforma funcional foram acompanhadas de uma reforma estrutural relativa ao "ser" do processo e da jurisdição, uma vez não poderem mais ser lidos senão com as lentes do neoconstitucionalismo.

Nesse diapasão, neste texto pretende-se realizar uma abordagem reflexiva sobre o direito processual civil e a jurisdição no que diz respeito à possibilidade de que, ambos, estejam tomando feições aqui denominadas de "pós-modernas". 
Como se sabe, o sentido que é atribuído a essa expressão é múltiplo. Tal multiplicidade existe na razão direta do olhar lançado sobre a contemporaneidade por aquele que tenta definir a expressão, já que o faz do lugar que ocupa. Assim, qualquer pretensão à uniformidade é vã. Economistas, filósofos, juristas, politólogos e sociólogos, entre outros, o que têm em comum ao tratar do tema, é pensar a contemporaneidade não como algo dado, como uma totalidade, mas algo em construção, em cujo contexto, o cenário cultural, econômico, filosófico, jurídico, político e social, dá mostras de fortalecer elementos que são modernos, por um lado e, por outro, romper com os mesmos, a partir da criação de novas formas de civilidade.

A pretensão de esgotar o tema segura e mimeticamente repetiria o mito de Sísifo. Sendo assim, escolhe-se tratar da pós-modernidade -e ligar essa reflexão ao campo do direito processual- tomando-se como fonte de inspiração a obra de Jacques Chevallier. Mas nesse momento a partir de apenas um olhar, isto é, de uma pós-modernidade que se faz hipermoderna e então retroalimenta elementos que nasceram com a modernidade e sofreram processo de lapidação ao longo de quase quatro séculos.

Como refere Nicola Picardi ${ }^{2}$, há uma vocação do tempo presente para a jurisdição, o que se expressa em âmbito mais global, uma vez serem os juízes os agentes mais ativos da chamada mundialização. ${ }^{3}$ Houve, como é sabido, uma inversão das tendências. De uma posição secundária a jurisdição passou a protagonista e o processo passou a ser o modo comum de resolução de setores inteiros como a família, os direitos sociais e a constitucionalidade das leis a demonstrar os desafios entre o ideal de querer viver em conjunto e as dificuldades da ação política. ${ }^{4} \mathrm{~A}$ judicialização da política internalizou essa complexidade e pode ser considerada resultado de dois fatores importantes: primeiro, da fragilidade dos sistemas políticos e, segundo, do quadro de declínio da reação dos governos às demandas da cidadania, como refere Rosanvallon. ${ }^{5}$

\footnotetext{
${ }^{2}$ PiCARDI, Nicola. Jurisdição e processo. Rio de Janeiro: Forense, 2008, pp. 1-33.

${ }^{3}$ Garapon, Antoine. Alard, Julie. Os juizes na mundialização. A nova revolução do Direito. Lisboa: Piaget, p. 8. E isso ocorre, particularmente, em face do fenômeno da internacionalização do Direito. Sobre essa problemática, vejam-se as liçōes de Mireille Delmas-Marty ministradas no Seminário da Cátedra Estudos Jurídicos Comparativos e Figuras da Internacionalização do Direito junto ao Collège de France no ano de 2008, disponível em http://www.college-de-france.fr/default/EN/all/int_dro/index.htm. Parte dessas lições esta traduzida e encontra-se postada junto ao Grupo de Estudos da obra de Mireille Delmas-Marty junto ao PPG em Direito da UNISINOS, coordenado pela ora autora. Trata-se do grupo grupo-de-estudos-delmasmarty@googlegroups.com.

${ }^{4}$ Garapon, Antoine. O guardador de promessas. Justiça e democracia. Lisboa: Piaget, p. 48.

${ }^{5}$ Rosanvallon, Pierre. La contre-democracie. La politique à l'age de la défiance. Paris: Seuil, 2006, pp. $232-$ 233.
} 
Entretanto, o fenômeno mais significativo produzido pela exacerbação do número de demandas é o descompasso entre o direito processual e a) a natureza das demandas; b) a internacionalização das relações jurídicas e do Direito e; c) a cultura da urgência, cujo traço marcante é a dinâmica permanente de mudança e que demarca a dominação sobre extensas esferas da vida social, tudo somado a reivindicar, no plano internacional, harmonização de regras processuais em reforço às bases da cooperação jurisdicional e, no plano interno dos Estados, a necessidade de reformas processuais.

Por outro lado, a importância jurídico-político-social em analisar-se o processo e a jurisdição sob essa ótica, centra-se na própria crise do Estado. A queda na confiança da atuação da jurisdição, como se percebe em pesquisas realizadas, ${ }^{6}$ não deixa de ser expressão de uma crise maior que acomete o Estado num cenário rico de multiplicidades e que remete a uma crise mais genérica das instituições e dos valores produzidos no curso da modernidade no Ocidente.

Desse modo, pode-se pensar estar em curso no Brasil o surgimento de um direito processual pós-moderno ${ }^{7}$ aqui analisado apenas com relação a apenas uma de suas faces: a hipermoderna. ${ }^{8}$ Para essa compreensão analisa-se a relação circular entre Pós-modernidade, neoliberalismo e hipermodernidade (Parte 1). Finaliza-se observando-se as reformas que prestigiam a quantidade em detrimento da qualidade em um processo marcadamente neoliberal (Parte 2).

\section{Parte 1. A relação circular entre Pós-modernidade, neoliberalismo e HIPERMODERNIDADE: A PROPÓSITO DE UMA JURISDIÇÃO MODELADA}

Haveria um ponto de coincidência entre a chamada pós-modernidade e o neoliberalismo? E se positiva a resposta, de qual pós-modernidade se está a tratar? Poderia ser essa entendida como hipermodernidade? Almeja-se aqui demonstrar ao leitor justamente essa imbricação entre pós-modernidade -neoliberalismohipermodernidade.

\footnotetext{
${ }^{6}$ Para se ter ideia desse fenômeno, pesquisa de avaliação do Judiciário no Estado do Rio Grande do Sul demonstra que os cidadãos colocam o Judiciário em quarto lugar em grau de confiabilidade, depois do Exército, da Igreja e da Polícia Federal. Pesquisa de avaliação do Judiciário no Estado do Rio Grande do Sul. Estado do Rio Grande do Sul. Poder Judiciário, nov./2009, p. 25.

${ }^{7}$ As referências que se farão neste texto dizem respeito às reformas processuais ocorridas apenas no processo civil, área de atuação da autora.

${ }^{8}$ Uma análise mais completa, em duas perspectivas é realizada pela autora em outro texto denominado de "Tempos de processo pós-moderno: O dilema cruzado entre ser hipermoderno e antimoderno". No prelo. A ser publicado em homenagem ao Professor Humberto Theodoro Junior.
} 
A expressão pós-modernidade tem sido alvo de várias definições -e divergências- semânticas, como já referido. Árduo é o caminho para chegar à confluência entre as várias perspectivas adotadas. Seria uma superação temporal da modernidade ou sua compreensão transcende espaço e tempo para alojar-se no campo da pura reflexão?

Parece ser possível afirmar que a pós-modernidade não é uma nova era que se instala em oposição à modernidade. Há uma visão da pós-modernidade que se posiciona na lacuna entre ser moderno e algo já diferente, então, uma visão em paralaxe, ${ }^{9}$ por permitir vislumbrar, como o fazem Agnes Heller e Ferenc Féher, ${ }^{10}$ que a pós-modernidade é parasitica da modernidade, uma vez que vive e alimentase de suas conquistas e de seus dilemas. Seu ineditismo estaria apenas presente na capacidade de pensar seu próprio tempo.

Contudo, parece ter sido Lyotard, ${ }^{11}$ no início da década de 70 do Século passado, o primeiro a fazer uso da expressão pós-modernismo afirmando que a atitude pós-moderna é aquela que desconfia das metanarrativas ${ }^{12}$ da modernidade, da busca do absoluto e da totalidade. Mas o embrião desse movimento de crítica à modernidade, sem que se fizesse uso do termo pós-modernidade, já se encontrava na Dialética do Esclarecimento de Adorno e Horkheimer, ${ }^{13}$ escrita em 1969, ao afirmarem que o "esclarecimento" consiste no cálculo da eficácia e da técnica de profusão e difusão e tudo o que não se reduzisse a números não passaria de uma ilusão, daí a inevitabilidade da destruição dos deuses e das qualidades.

De outra parte, a idéia de modernidade reflexiva pode-se dizer, a risco de errar, é uma variante da pós-modernidade e que implica na possibilidade de a

${ }^{9}$ Para Žižek, a paralaxe permite que se compreendam fenômenos mutuamente intraduzíveis a partir de um ponto de vista sempre mutável entre dois pontos entre os quais não há síntese nem mediação possível. Reconhece o autor que há uma série de modos de paralaxe em domínios distintos da vida como da física quântica, da neurobiologia, da diferença ontológica, etc. Žıž̌K, Slavoj. A visão em paralaxe. São Paulo: Boitempo, 2008, pp. 14 e 18.

${ }^{10}$ FéHer, Ferenc. Heller, Agnes. A condição política pós-moderna. Rio de Janeiro: Civilização Brasileira, 1998, p. 23, publicação original datada de 1987. Para Agnes Heller o "nosso mundo (o mundo em que a condição pós-moderna pode encontrar morada) é profundamente problemático" e deve ser revelado dia-adia. In: Heller, Agnes. FéHer, Ferenc. Politicas de la posmodernidad. Ensayos de la crítica cultural. Barcelona: Ediciones Península, 1989, p. 23.

${ }^{11}$ Lyotard, Jean-François. A condição pós-moderna. São Paulo: José Olympio, 2008.

${ }^{12}$ Contudo, Anderson, Perry destaca o equívoco de Lyotard pois, ao invés de caírem as grandes metanarrativas o mundo caía na maior delas: a vitória global do mercado a partir dos anos 80 do Século passado. As origens da pós-modernidade. Rio de Janeiro: Zahar, 1999, p. 39.

${ }^{13}$ Adorno, Theodor. Horkheimer, Max. Dialética do esclarecimento. Fragmentos filosóficos. Rio de Janeiro: Zahar, 1985, pp. 15 e 20. 
modernidade olhar para si para si mesma e para seus vícios. Ela pode justamente ser compreendida no contexto sugerido por Adorno e Horkheimer, uma vez que a modernidade, surgida como emancipação da ordem estática pré-moderna, abriu possibilidades para a liberdade de expressão, para a democracia popular e para o desenvolvimento do livre mercado capitalista e acabou por voltar-se contra si mesma e transformou-se numa assombração. ${ }^{14}$ Mas um autor como David Harvey ${ }^{15}$ afirma que "uma das condiçôes principais da pós-modernidade é o fato de ninguém poder ou dever discuti-la como condição histórico-geográfica”, ou seja, o prefixo "pós" está desconectado de um sentido cronológico e implica que "os longos e sérios esforços da modernidade foram enganosos, foram empreendidos sob falsas pretensões, e estão destinados a terminar" ${ }^{16}$ A modernidade, ${ }^{17}$ ela mesma, estaria encarregada de demonstrar a própria falência, a sua própria impossibilidade, a vaidade de suas esperanças e o desperdício de seus trabalhos.

Realizadas essas breves análises e considerando-se as posições em defesa da continuidade da modernidade ${ }^{18}$ ou em defesa da ruptura ${ }^{19}$, com ela reivindicase nesse momento o registro feito por Agnes Heller e Ferenc Féher de que a pós-modernidade é parasítica da modernidade, uma vez ser fundamental para a compreensão da hipermodernidade, como proposta por Jacques Chevallier. ${ }^{20}$ Esse autor convoca a que se pense a pós-modernidade não como algo que atingiu seu ápice e tampouco como algo a ser totalmente superado. No mo-

${ }^{14}$ Giddens, Anthony. Beck, Ulrich. LaSh, Scott. Modernização reflexiva. São Paulo: Unesp, 1997, p. 12 e 137. Estes autores preferem usar a expressão modernidade reflexiva ao invés de pós-modernidade. Para eles, a modernização reflexiva consiste na possibilidade de uma autodestruição criativa para toda uma era, ou seja, a desincorporação e depois, a reincorporação das formas sociais industriais por outra modernidade.

${ }^{15}$ Harvey, David. Condição pós-moderna. São Paulo: Loyola, 2009, p. 301.

${ }^{16}$ Bauman, Zygmunt. Ética pós-moderna. Rio de Janeiro: Zahar, 2006, p. 15.

${ }^{17}$ Toma-se emprestado a referência de Vattimo sobre modernidade, construída a partir do pensamento de Nietzsche e Heidegger, no sentido de que se caracteriza por ser dominada pela ideia do pensamento como iluminação progressiva, que se desenvolve pela apropriação e reapropriação cada vez mais plena de fundamentos, pensados também como as origens. VATTIMO, Giovanni. O fim da modernidade. Niilismo e hermenêutica na cultura pós-moderna. São Paulo: Martins Fontes, 2002, p. VI. Para BAuman, Zygmunt. O mal-estar da pós-modernidade. Rio de Janeiro: Zahar, 1997, p. 8, a modernidade é mais ou menos beleza, limpeza e ordem e, por isso, a civilização moderna, segundo o autor construiu-se sobre uma renúncia ao instinto. E o elemento novo, da pós-modernidade é que a união da beleza, da limpeza e da ordem é feita por um novo homem, demasiado humano, que reclama prazer, cada vez mais prazer e, com isso, eleva o individualismo e a liberdade pessoal reina soberana.

${ }^{18}$ Como pensam Anthony Giddens, Ulrich Beck e S. Lash.

${ }^{19}$ Posição de Zigmunt Bauman que tratará da chamada modernidade líquida.

${ }^{20}$ Chevallier, Jacques. O Estado pós-moderno. Belo Horizonte: Editora Fórum, 2009, pp. 19-20. 
mento em que envereda pela análise do Estado Pós-Moderno, esclarece que as sociedades ocidentais entraram numa nova era: a da hipermodernidade e da antimodernidade.

A noção de hipermodernidade dada por Chevallier e captada neste momento, inspira-se no pensamento de François Aschter, ${ }^{21}$ para quem a modernidade seria conformada por três fases: a) a primeira, identificada como "tempos modernos", inicia ao final da Idade Média, estende-se até o princípio da Revolução Industrial, demarca a modificação do lugar e do papel da religiāo, a emancipação da política e surgimento de uma nova forma de Estado; b) a segunda, em que a produção de bens e serviços obedece a lógica capitalista e a técnica ocupa o lugar central nas sociedades ocidentais e finalmente; c) a terceira, em que não há uma superação da segunda modernidade, como querem os defensores da pós-modernidade e sim um continiuum em cujo contexto aparece um novo indivíduo, o multimensional, por sua capacidade de adotar personalidades distintas a depender do lugar em que se encontre, possibilidade que decorre da conformação social em rede de relações.

Então aqui visível a pós-modernidade que se faz hipermoderna e que interessa aos limites propostos neste trabalho.

Dessas dimensões, são particularmente visíveis a busca da certeza da quantificação, a segurança das respostas sempre iguais, o indivíduo colocado como homem livre para escolher, então transformado em consumidor, entre outras. De fato, essas são algumas das marcas identificadoras da sociedade liberal e capitalista, nascida ao final do Século XVIII e vertida em sua forma mais arrojada, a partir do final da década de sessenta do Século passado, em neoliberalismo. Na verdade, a "neoliberalização" necessitava de uma cultura fundada no mercado para promover o "consumismo diferenciado e o libertarianismo individual". ${ }^{22}$

Do homo economicus ${ }^{23}$ do Século XVIII, então homem da sociedade da troca, que impunha uma peculiar "razão de Estado" ou "razão governamental" moderna que era a limitação da arte de governar ou, do mesmo modo, "não governar demais", passa-se ao homem empresário neoliberal que se transforma no seu próprio capital, sendo para si mesmo seu produtor, culminando, em consumidor

\footnotetext{
${ }^{21}$ AsChTER, François. Diário de um hipermoderno. Madrid: Alianza Editorial, 2009.

${ }^{22}$ Harvey, David. O neoliberalismo. História e implicaçôes. São Paulo: Edições Loyola, 2008, p. 52.

${ }^{23}$ Expressão utilizada por Foucault, M. Nascimento da biopolítica. São Paulo: Martins Fontes, 2008, p. 201. Diz o autor: "O homo oeconomicus que se quer reconstituir não é o homem da troca, não é o homem consumidor, é o homem da empresa e da produção".
} 
ao final convertido em mercadoria, ${ }^{24}$ mergulho numa antropologia artificialista, ${ }^{25}$ fundada no sujeito de prazer e de interesse que liga direito e economia.

$O$ viés identificador da matriz econômico-política do liberalismo daquele Século a que Adam Smith ${ }^{26}$ denominou de "mão invisível", com a peculiaridade de que sua preocupação estava voltada à sustentação da atividade interna do Estado em contraposição à estrangeira, em muito pouco se identifica com a sociedade concorrencial do neoliberalismo, em que as empresas ocupam o papel fundamental e os seus critérios de gestão -na atualidade- espalham-se para a esfera pública, como a do Poder Judiciário.

$\mathrm{Na}$ economia de mercado da atualidade, o que está em questão é que essa espécie de economia sirva de princípio, de forma e de modelo para o próprio Estado. ${ }^{27} \mathrm{O}$ problema fundamental do neoliberalismo, mais do que antes, é manter a regulação do exercício global do poder político com base naquela economia de mercado, mas agora sob o signo arrojado da abstração, da estandardização, da concorrência e da quantificação. Quando isso acontece, o abstrato toma o lugar do concreto e passa a representar a "normalidade abstrata" de que se nutre o neoliberalismo para impor padrões de conduta e padrões de gestão.

Eis que já não se trata simplesmente de analisar o individualismo ou o neoindividualismo ${ }^{28} \mathrm{em}$ si sob o ponto de vista de uma possível patologia individual e sim da patologia da sociedade ocidental, como referiu Erich Fromm. ${ }^{29}$ Essa fineza de percepção é precisamente o que o leva a reconhecer que a sociedade em que as atividades econômicas hajam se convertido na principal preocupação dos homens, o processo de abstração e quantificação ultrapassa o campo econômico e passa a refletir as atitudes comportamentais dos homens em geral frente às coisas, às pessoas e perante si mesmo.

Disso foi apenas um passo para que as instituições estatais, como o Poder Judiciário, passassem a padecer da mesma patologização. $\mathrm{Na}$ condição de uma

\footnotetext{
${ }^{24}$ Bauman, Zygmunt. Vida para o consumo. A transformação das pessoas em mercadoria. Rio da Janeiro: Zahar, 2008, p. 20.

${ }^{25}$ FoesSel, Michael. Néolibéralisme versus libéralisme? Esprit. Dans la tourmente (I). Aux sources de la crise financière. Nov/2008. Paris, p. 80.

${ }^{26}$ SMith, Adam. A riqueza das Naçôes. Vol. I. São Paulo: Martins Fontes, 2003, p. 567.

${ }^{27}$ Foucault, M. Nascimento da biopolitica, p. 159.

${ }^{28}$ CAstanheira Neves, A. O direito interrogado pelo tempo presente na perspectiva do futuro. Boletim da Faculdade de Direito. Coimbra: Coimbra, 2007, p. 11.

${ }^{29}$ Fromm, Erich. Psicoanálisis de la sociedade contenporánea. México: Fondo de Cultura Econômica, 2006, p. 99.
} 
instituição burocrática moderna, pode-se dizer que o Judiciário não restou incólume às disfunções que ameaçam o processo judicial, do que a sociedade tem tanto reclamado, ora porque o Judiciário mantém-se, na perspectiva weberiana, extremamente jungido à lei e, assim, afasta-se da singularidade do caso, ${ }^{30}$ ora, na perspectiva de Hannah Arendt, ${ }^{31}$ porque ele cada vez mais fragmenta-se e afasta $o$ juiz das experiências intelectuais que devem informar seu julgamento, para que a decisão deixe de ser uma escolha mecânica feita nos gabinetes ou na virtualidade, hoje, do processo eletrônico. Quanto mais fragmentada, mais se corre o risco de provocar a mesma ausência de pensamento nas decisões judiciais como aquela encontrada por Arendt em Eichmann. ${ }^{32}$

Essas premissas postas em um contexto de análise mais global, só poderão conduzir ao reconhecimento de que a atitude "salvadora" de muitos Estados em relação às instituições financeiras globais, quando da crise financeira de 2008, é a confirmação -e a denúncia- dessa "arte de governar" em que no jogo econômico os únicos parceiros são as empresas e para as quais a atividade vigilante do Estado é cara. ${ }^{33}$ Com mais razão, no jogo das políticas de livre mercado, que fomenta a iniciativa privada, a liberdade do consumidor, a responsabilidade pessoal e a iniciativa empresarial, um número relativamente pequeno de interesses privados controla a vida social e reivindica do Estado uma atitude servil a que, invariavelmente e infelizmente, as democracias representativas têm se prestado.

Defender a coisa pública ou os direitos humanos sociais, por exemplo, em detrimento dos interesses econômicos, sob a ótica neoliberal, resulta no mínimo atitude suspeita na medida em que interfere no mercado livre, "que se postula como o único assinador racional, justo e democrático de bens e serviços”. ${ }^{34}$

Desse modo, a partir do momento em que o neoliberalismo agrega outros elementos àqueles já plantados pela modernidade que se confundem, em boa medida ao próprio espírito do capitalismo ${ }^{35}$-ideia de progresso material; eficácia

\footnotetext{
${ }^{30}$ Sobre o tema, consulte-se o rico texto de BAPTISTA DA SILVA, Ovídio Araújo. A Justiça da lei e a justiça do caso http://www.baptistadasilva.com.br/artigos008.htm. Acesso em 27 dezembro de 2009.

${ }^{31}$ ARENDT, Hannah. Eichmann em Jerusalém: um relato sobre a banalidade do mal. São Paulo: Diagrama \& Texto, 1983.

${ }^{32}$ Lembrança referida por FIss, Owen. Um novo processo civil. Estudos norte-americanos sobre jurisdição, constituição e sociedade. São Paulo: RT, 2004, p. 183.

${ }^{33}$ Foucault, M. Nascimento da biopolitica, p. 182.

${ }^{34}$ Chomsky, Naom. El beneficio es lo que cuenta. Neolilberalismo y ordem global. Barcelona: Crítica, 1999, pp. 7-8.

${ }^{35}$ Boltanski, Luc. Chiapello, Ève. O novo espirito do capitalismo. São Paulo: Martins Fontes, 2009, p. 45.
} 
e eficiência na satisfação das necessidades; modo de organização social favorável às atividades econômicas-, serve-se da feição hipermoderna da pós-modernidade e exige das instituições estatais funcionamento e estrutura compatíveis com o valores concorrência, estratégia e planificação.

Com argúcia, já na década de 70 do Século passado, Michel Foucault ${ }^{36}$ referiu que a lei não passa, muitas vezes de uma simples regra do jogo e que cada um exerce o poder que lhe toca. Por isso, o Judiciário, ao invés de manter-se como simples la bouche de la loi, é chamado a exercer nova autonomia e adquire uma importância destacada. A secundariedade da Jurisdição, própria do Estado Liberal, dá lugar ao protagonismo. Não sendo mais o sujeito econômico o homem da troca liberal e sim a empresa do neoliberalismo, refinada expressão de uma "certa maneira de se comportar" no campo econômico, mais as superfícies de atrito com os indivíduos produzidos pela própria lógica neoliberal -atomizados, desconexos, desmoralizados e socialmente impotentes ${ }^{37}$ aumentam e mais conflitos surgem a exigir um intervencionismo Judiciário que, segundo o filósofo, "deve servir como arbitragem das regras do jogo".

É exatamente esse jogo que põe em cena a relação de circularidade entre pósmodernidade, neoliberalismo e hipermodernidade. É necessário que o processo e a jurisdição modelem-se aos interesses neoliberais, alinhem-se à quantificação e ao fluxo, por meio de um conjunto de reformas que conjugam esforços para funcionar melhor, ser eficiente e compatibilizar os tempos do processo com o tempo da economia. É disso que trata o próximo item.

\section{Parte 2. Crônica de uma morte anunciada: As reformas Que Prestigiam a QUANTIDADE E DESPREZAM A QUALIDADE EM UM PROCESSO NEOLIBERAL}

$\mathrm{Na}$ "Crônica de uma morte anunciada" ${ }^{38}$, Santiago Nasar, o personagem central da trama criada por Gabriel Garcia Marquez, estava destinado a morrer. $\mathrm{Na}$ cidade, a maior parte dos moradores tinha conhecimento de seu trágico fim. No entanto, tal como os cegos para a vida, Santiago manteve-se cego à própria morte. A estória pode ser a grande metáfora do direito processual civil e da Jurisdição: um grande quebra-cabeça, desafiado pelos anseios de mudanças em que as reformas processuais já empreendidas no Brasil e as que estão em curso parecem anunciar a morte do que se pode identificar no processo civil brasileiro como

${ }^{36}$ Foucault, M. Nascimento da biopolitica, p. 240.

${ }^{37}$ Сномкку, Noam. El beneficio es lo que cuenta, p. 12.

${ }^{38}$ Garcia Marquez, Gabriel. Crônica de uma morte anunciada. Rio de Janeiro: Record, 2009. 
comprometido com uma prestação jurisdicional que prime pela qualidade, com as bases constitucionais da decisão e orientada por princípios.

O anseio por reformas, na perspectiva -talvez vã- de que os problemas cruciais da prestação da jurisdição tenham fim, tem permitido aos juristas em geral e aos processualistas, em particular, perceber que muitas dessas reformas podem consistir na morte anunciada do processo de qualidade? Não haveria, como refere Lenio Streck, ${ }^{39}$ uma asfixia da realidade a impedir o desenvolvimento de uma discussão filosófica acerca do tema? Sobretudo no que diz respeito ao problema da teoria da decisão ${ }^{40}$ e da filosofia da linguagem, caminho possível para colocar-se em xeque o problema do solipsismo decisório e, quiçá, reorientar a perspectiva da decisão para argumentos de princípio e não de política. Quanto a essa última, para romper com o perfil regulatório, submisso à funcionalização ${ }^{41} \mathrm{e}$ de instrumento sancionador de quaisquer outras e externas ideologias a que foi reduzido o Direito ${ }^{42}$ na perspectiva moderno-iluminista e, por consequência, a própria Jurisdição.

Sendo induvidoso o quadro de reformas processuais ocorridas no Brasil, particularmente no que se refere àquelas ocorridas a partir da Emenda Constitucional No 45 de dezembro 2004 e considerando-se a existência de uma Comissão de Juristas $^{43}$ incumbida de apresentar projeto de novo Código de Processo Civil, pergunta-se se haveria relação dessas reformas com os interesses neoliberais e em

\footnotetext{
${ }^{39}$ Streck, Lenio. Novo Código de Processo Penal. O problema dos sincretismos de sistemas (inquisitorial e acusatório). Revista de Informação Legislativa. Brasília. Ano 46. No 183. jul/set - 2009, p. 123.

${ }^{40}$ Sobre o tema também em STRECK, Lenio. O que é isto - decido conforme minha consciência? Porto Alegre: Livraria do Advogado, 2010.

${ }^{41}$ Sobre o tema ver: BAPTISTA DA Silva, Ovídio Araujo. Da função à estrutura. Constituição, Sistemas Sociais e Hermenêutica. Anuário 2008. Programa de Pós Graduação em Direito UNISINOS. Porto Alegre: Livraria do Advogado, 2008, pp. 89-100. SaldanHa, Jânia Maria Lopes. Do funcionalismo processual da aurora das luzes às mudanças estruturais e metodológicas do crepúsculo das luzes: A revolução paradigmática do sistema processual e procedimental de controle concentrado de constitucionalidade no STF. Constituição, Sistemas Sociais e Hermenêutica. Anuário 2008. Programa de Pós Graduação em Direito UNISINOS. Porto Alegre: Livraria do Advogado, 2008, pp. 113-134.

${ }^{42}$ Castanheira Neves, A. O direito interrogado, p. 6. Mas também uma promessa de gozo, em um mundo em que o que "o que conta é o número de processos julgados no final do mês, em que qualidade é contigência”. ROSA, Alexandre Morais da. Aroso Linhares, José Manuel. Diálogos com a Law \& Economics. Rio de Janeiro: Lúmen Júris, 2009, p. 64.

43 A Comissão criada pelo Ato No 379, de 2009, do Presidente do Senado Federal, é composta pelos juristas Adroaldo Furtado Fabrício, Benedito Cerezzo Pereira Filho, Bruno Dantas, Elpídio Donizete Nunes, Humberto Theodoro Junior, Jansen Fialho de Almeida, José Miguel Garcia Medina, José Roberto dos Santos Bedaque, Marcus Vinicius Furtado Coelho, Paulo Cezar Pinheiro Carneiro, Teresa Arruda Alvim Wambier, como Relatora-Geral dos Trabalhos. Disponível em: http://www.senado.gov.br/sf/senado/novocpc/. Acesso em 30 de dezembro de 2009.
} 
que medida poderiam elas ser consideradas reformas pós-modernas no sentido hipermoderno?

Visualiza-se nesse passo, a risco de toda crítica, uma aproximação entre as reformas processuais e os interesses neoliberais. Pode-se constatar que o modelo reformista brasileiro, se em aparência prometia atribuir aumento aos poderes dos juízes -com a antecipação de tutela em 1994 e mais recentemente com a sentença indeferitória liminar, por exemplo-em evidente comprometimento com as teorias sociológicas a que no Brasil defensores da instrumentalidade, ${ }^{44}$ renderam homenagens, ao fim e paulatinamente, tais reformas têm esvaziado o papel do processo como instituição constitucional garantidora dos direitos fundamentais. Mais grave. Institutos como a sentença liminar por resultar de um modelo prévio, pré-dado, implicam em negação ao acesso à Justiça por meio de uma decisão estandardizada. E assim sendo, violam não só o artigo $5^{\circ}, \mathrm{XXXV}$, da Constituição Federal quanto textos normativos internacionais de que o Brasil é signatário, como o artigo $8^{\circ} \mathrm{da}$ Convenção Interamericana dos Direitos Humanos que prevê ter toda pessoa "o direito de ser ouvida com as devidas garantias...”.

Esse dispositivo garante o acesso à Justiça como um direito humano que implica no direito de ser ouvido, então, no direito de participar de um processo em contraditório e com base na ampla defesa. Tal princípio, aliás, conforma a própria noção de dignidade humana, o chamado "mínimo invulnerável” ${ }^{45}$ do ser humano que o ordenamento jurídico deve assegurar mas que é negado, tanto quanto o é o próprio princípio da convencionalidade ${ }^{46}$ previsto no artigo $2^{\circ}$ daquela Convenção.

Todavia, haveria uma relação estreita entre a vocação do tempo presente para a jurisdição - com a acentuada demanda ao Judiciário- e a democracia constitucional? É a Justiça um espaço de exigibilidade de democracia na medida em que deve zelar para a convergência e concretização de "valores e necessidades vitais" ${ }^{47}$ afirmados historicamente e que compóem o quadro dos direitos fundamentais?

\footnotetext{
${ }^{44} \mathrm{O}$ expoente dessa posição no Brasil é o Professor Cândido Rangel Dinamarco porque estabelece centralidade à jurisdição ao defender uma instrumentalidade positiva norteada por escopos metajurídicos-jurídico, social, político e econômico. O que defende, pois, é uma racionalidade meramente instrumental para o processo e não uma racionalidade discursiva. DinAmarCo, Cândido Rangel. Instrumentalidade do processo. São Paulo: Malheiros, 2005.

${ }^{45}$ Alcalá Nogueira, Humberto. Dignidade de la persona, derechos fundamentales y bloque constitucional de derechos: Uma aproximação desde Chile e América Latina. In: Velandia Canosa, Eduardo Andres. (Coord.). Derecho Procesal constitucional. Colombia: Agencia Imperial, 2010, p. 592.

${ }^{46}$ CANTOR, Ernesto Rey. Control de convencionalidad de las leyes y derechos humanos. México: Editorial Porrúa, 2008.

${ }^{47}$ Ferrajoli, Luigi. Los fundamentos de los derechos fundamentales. In: Ferrajoli, Luigi. Los fundamentos de los derechos fundamentales. Madrid: Editorial Trotta, 2007, p. 372.
} 
No que interessa aos contornos desse trabalho pode-se dizer que sim se a referência for à necessidade da jurisdição para que sejam efetivados direitos fundamentais no quadro de um processo constitucionalizado ${ }^{48}$ e normativamente disciplinado pelos direitos fundamentais, em que de mero instrumento -e superando-se as teorias instrumentalistas- passa a ser o garante dos direitos fundamentais ${ }^{49}$ e ele próprio deve ser obedecer à Constituição. Mas por outro lado, pode-se vislumbrar na Jurisdição apenas uma função instrumental a serviço dos interesses do mercado para a redução da complexidade social, garantia e segurança dos negócios, dotado de plena previsibilidade. Afinal, nesse sentido, Milton Friedman em seu Capitalismo e Liberdade afirma que obter benefícios é a essência da democracia. Por essa razão todo o governo -e aqui, toda a jurisdição- que seguir políticas contrárias é antidemocrático ${ }^{50}$ e adotar posições garantistas, ${ }^{51}$ como determina a Constituição Federal, significa para os críticos dessa estirpe fazer aposta em favor da burocratização. Daí ser importante estimulá-lo a garantir a propriedade privada e respeitar contratos, limitando-se o debate político e, no campo jurisdicional, desprestigiando-se o conteúdo das decisões que devem ser comprometidos com os valores constitucionais e estimulando-se a quantificação e o fluxo.

Desde o ano de 1996 o Banco Mundial fornece orientações paranormativas ao Brasil sinalizando a necessidade de que houvesse uma reforma do Judiciário e do processo no País. Assim, pretende-se demonstrar, à partida, a estreita relação entre as reformas processuais ocorridas no sistema processual brasileiro nos últimos anos e a atividade paranormativa de agências transnacionais de fomento junto aos países periféricos, como o Banco Mundial. Tal atividade está retratada em dois

\footnotetext{
${ }^{48}$ CANTOR, Ernesto Rey. El derecho procesal constitucional. Um nuevo concepto. Bogotá: Ediciones Doutrina y Ley Ltda., 2010.

${ }^{49}$ Nunes, Dierle José Coelho. Processo jurisdicional democrático, p. 147.

${ }^{50}$ Percuciente denúncia foi feita nesse sentido por Calmon de Passos ao afirmar um dos graves problemas das reformas processuais foi ter como objetivo primordial alcançar solução apenas para o sufoco em que vive o Poder Judiciário, em razão de sua antidemocrática e burocratizante institucionalização constitucional. Não teria havido, segundo o autor, preocupação com as causas, as quais restaram impensadas e por isso, deu-se lugar às palavras mágicas como celeridade, efetividade e desformalização. CalmON DE PASsos, J.J. Instrumentalidade do Processo e devido processo legal. Revista Sintese de Direito Civil e de Direito Processual Civil. n. 7. Porto Alegre: Síntese, 2000, p. 14.

${ }^{51} \mathrm{O}$ processo penal brasileiro também não escapou da influência neoliberal. A introdução da lógica da negociação transformou o processo penal, segundo Auri Lopes Júnior, em um mercado persa. Daí sua crítica à justiça negociada preconizada pelos Juizados Especiais Criminais, submetidos às influências do law and order, que banaliza o direito penal e desconsidera a perspectiva garantista dos direitos. LOPES JúNIOR, Auri. Justiça negociada. Utilitarismo processual e eficiência antigarantista. In: Diálogos sobre a justiça dialogal. Teses e antíteses sobre os processos de informalização e privatização da justiça penal. Rio de Janeiro: Lumen Juris, 2002, pp. 110-111.
} 
documentos técnicos do Banco Mundial para o Poder Judiciário do Brasil que serão brevemente analisados na seqüência.

Nesse ponto, o objetivo será tentar demonstrar o íntimo vínculo entre as exigências de otimização dos serviços do Poder Judiciário, em termos de fluxo com o coração do processo de globalização: logo, com o neoliberalismo, assumido pelo Brasil a partir da década de 80 do Século passado, cujo reflexo se faz sentir, sobremaneira na função e estrutura do direito processual e da jurisdição.

O modelo de Estado, como refere Mirjan Damaska, desenha o tipo de processo que se tem, ou seja, tanto a organização do Poder Judiciário quanto o seu modo funcional de administração deixam marcas evidentes no processo. Desse modo, embora a Constituição Federal do Brasil no artigo $1^{\circ}$ estabeleça o Estado Democrático de Direito, é certo que sob o ponto de vista econômico e da atuação dos governos, a roupagem é a de um Estado que fez a nítida opção pelo modelo neoliberal. A pergunta posta por Damaska ${ }^{52}$ é emblemática: "La pregunta no es solo qué tipo de procedimiento queremos, sino también qué tipo de organización del Estado poseemos". Essa assimilação, como referido, é sustentada pelo consenso econômico neoliberal. Percebe-se bem que a subordinação dos Estados nacionais às agências multilaterais como o Banco Mundial, FMI e a Organização Mundial do Comércio consiste numa das três importantes inovações institucionais ${ }^{53}$ que a receita neoliberal provoca.

O Banco Mundial, ${ }^{54}$ ao contrário de outras organizações internacionais, busca padronizar as concepções de Judiciário e de justiça de forma meramente indicativa. A adesão dos Estados não se dá pela via de normas e sim pela adesão a ideias. O que nem por isso significa não ter impacto em nível interno. Um dos instrumentos da atividade paranormativa do Banco são as publicações e documentos a respeito do Judiciário. O domínio de sua influência sobre o Poder Judiciário dos Estados ocorre basicamente em dois níveis: a) institucional -o Poder Judiciário deve ser enquadrado num processo de modernização e; b) individual -os juízes são construtores de consenso.

\footnotetext{
${ }^{52}$ DamaSKa, Mirjan. Las caras de la justicia y el poder del Estado. Análisis comparado del proceso legal. Santiago: Editorial Jurídica de Chile, 2000, p. 86.

${ }^{53}$ As outras duas são: a) restrições drásticas à regulação estatal da economia; b) novos direitos de propriedade internacional para investidores estrangeiros. Consulte-se: SANTOS, Boaventura de Sousa. Os processos de globalização. In: SAntos, Boaventura de Sousa (Org.). A globalização e as ciências sociais. São Paulo: Cortez Editora, 2002, p. 31.

${ }^{54}$ Em 1997 o Banco Mundial promove a discussão sobre o novo papel do Estado. Em 2000 realiza a Primeira Conferencia Mundial sobre o judiciário, em cujo âmbito se debate o sucesso do judiciário. Em 2002 realiza-se nova Conferência em se analisam instituições que promovem mercados para melhorar a renda e reduzir a pobreza.
} 
A confecção dos Documentos Técnicos e Relatórios sobre o Judiciário, assim, pretende expor essas feridas apontadas pelo Banco. Com isso, orientar os governos aos interesses particulares dessa agência de fomento financeiro, disfarçados sob a retórica da necessidade de dar mais qualidade à prestação jurisdicional, nada mais significa do que o discurso deliberado para condicionar o jurídico.

Colhe-se, genericamente, do Documento Técnico 319S -O setor Judiciário na América Latina e no Caribe- do ano de 1996, que o Banco Mundial, sob um discurso aparentemente neutro, recomenda como valores para o "aprimoramento" da prestação jurisdicional os seguintes: a) previsibilidade nas decisões; b) independência; c) eficiência; d) transparência; e) credibilidade; f) combate à corrupcão; g) protecão à propriedade privada; h) acessibilidade e; i) respeito aos contratos; j) mudança no ensino jurídico. No Brasil, a Emenda Constitucional 45 de 2004 que implementou a chamada "Reforma do Judiciário" recepcionou significativamente tais recomendações.

No que diz com a previsibilidade (a) das decisóes o Banco entende que o Poder Judiciário deve atuar com o valor certeza, porquanto, sob o ponto de vista dos interesses econômicos, se um Estado -e suas instituições- mudam as regras do jogo no percurso da partida, as empresas não poderão saber o que será lucro ou não no futuro. Logo, o fluxo de investimentos financeiros tende a reduzir-se.

A previsibilidade sistêmica, para o Banco Mundial, deve ser um valor a ser desenvolvido e preservado. Essa foi uma nada sutil ocasião para a justificação da criação da súmula vinculante, da repercussão dos recursos extraordinário e especial e da súmula impeditiva de recursos e, para atender as exigências em favor da previsibilidade. ${ }^{55}$ Das estatísticas do Supremo Tribunal Federal pode-se constatar uma estreita relação, ${ }^{56}$ por exemplo, entre a criação do critério da repercussão

\footnotetext{
${ }^{55} \mathrm{Na}$ época da elaboração da EC 45/2004 os juízes de primeiro grau foram refratários à adoção da súmula vinculante.

${ }^{56}$ A Lei 11.418 de dezembro de 2006 regulamentou a repercussão geral do recurso extraordinário. Desde o ano de 2007 passou-se a perceber uma queda no ingresso desses recursos junto ao STF. Veja-se que em 2007 foram 49.708. Em 2008 foram 21531 e em 2009 até o mês de novembro, 7.656. Os processos distribuídos com preliminar de repercussão geral em 2007 foram 4.784 em 2007; 25.885, em 2008 e; 20.854 em 2009. Existem atualmente 24 súmulas vinculantes. Três foram editadas em 2007. Dez em 2008 e onze em 2009. Há uma relação direta entre as matérias reconhecidas como de repercussão geral e as súmulas vinculantes. Os números e os gráficos apresentados pelo STF demonstram, induvidosamente, que a adoção do óbice recursal -a repercussão geral- reduziu significativamente o número de recursos extraordinários que chegam ao STF e, por outro lado, um aumento, desde 2007, das súmulas vinculantes. Assim, se o valor preponderante é a quantificação e o fluxo, pode-se afirmar que, funcionalmente, o STF tem cumprido com essa função. Resta indagar, em termos de qualidade substancial, se a Justiça tem cumprido seu papel, uma vez que há milhôes de recursos represados nos Tribunais de segundo grau à espera do julgamento das preliminares de repercussão geral junto ao STF. Dados disponíveis em http://www.stf.jus.br/arquivo/cms/jurisprudenciaSumulaVinculante/ anexo/Enunciados_1_a_24_da_Sumula_Vinculante.pdf. Acesso em 30 de dezembro de 2009.
} 
geral, a redução do número de recursos extraordinários e a criação das súmulas vinculantes. Nesse sentido, Maria Tereza Sadek ${ }^{57}$ refere que essas reformas trouxeram "mudança significativa" no perfil dos Tribunais brasileiros, no volume e na qualidade decisória das sentenças.

Embora não se possa discordar totalmente das mudanças provocadas, tampouco negar a importância da pesquisa realizada pela referida autora, a conclusão a que chega confirma a visão que vê na "função" a crise do judiciário e que, por tal razão, no aprimoramento dos critérios de gestão judiciária estaria a saída para a crise. Nesse sentido, no ano em curso, o Conselho Nacional de Justiça objetivando concretizar a Meta 8 e o quinto objetivo estratégico, firmou o propósito de que $50 \%$ dos juízes brasileiros submetam-se a curso de gestão judiciária à distância pelo período de 40 horas, com o fim de gerenciar rotinas de forma "racional e eficiente" ${ }^{58}$

Entretanto, um dos resultados mais claros desse conjunto de reformas é, com efeito, a fragilização do ato decisório como o momento magno da compreensão e do encontro do sentido do caso, uma vez que o juiz deverá obedecer a súmula vinculante, encontrando apenas nela os elementos para assegurar a legitimação de sua decisão. Prestigia-se o pré-dado e a normatização. Decreta-se a morte da interpretação ${ }^{59}$ e corre-se o risco de abandono de uma das virtudes -e um princípio- da democracia que é o princípio do devido processo legal constituído pelo contraditório, ampla defesa e direito à decisão fundamentada. O que é propalado como solução para os males da prestação jurisdicional, traduz-se em obstáculo democrático ${ }^{60}$ utilizado por meio do direito processual que nessa medida continua a ser utilizado de forma hegemônica. A Justiça assim, deixa de ser a da "justa medida" ou a da resposta constitucionalmente adequada por não combinar com o paradigma iluminista da abstração que a súmula vinculante veio revigorar.

\footnotetext{
${ }^{57}$ SADEK, Maria Tereza. Inovar para julgar mais rápido. Conjur. Disponível em: http://www.conjur.com. br/2009-fev-11/reforma-judiciario-propiciou-mudancas-acelerar-justica. Acesso em 03 de junho de 2010.

${ }^{58}$ Informação disponível em: http://www.cnj.jus.br/index.php?option=com_content\&view=article\&id=10 955:metade-dos-magistrados-brasileiros-sera-capacitada-em-administracao-judiciaria\&catid=1:notas\&Item id=169. Acesso em 02 de junho de 2010.

${ }^{59}$ Notícia publicada no sítio do STJ em 11 de agosto de 2009 demonstra que a atenção à previsibilidade e quantidade toma o lugar da preocupação com a qualidade. Diz a notícia que: "Ministro Luis Felipe Salomão nega $90 \%$ dos agravos analisados em mutirão.O mutirão realizado no último sábado (8) pelo ministro Luis Felipe Salomão superou as expectativas do gabinete. A meta era analisar 250 agravos de instrumento no dia, mas a equipe de dezessete servidores atingiu a marca de 300 processos. Aproximadamente $90 \%$ dos casos foram negados por descumprir exigências formais ou esbarrar nas súmulas que impedem a análise do recurso pelo STJ. [...]" Disponível em: http://www.stj.gov.br/portal_stj/publicacao/engine.wsp. Acesso em 11.08.2009.

${ }^{60}$ STReCK, Lenio. O que é isto - decido conforme minha consciência? Porto Alegre: Livraria do Advogado, 2010, p. 42.
} 
Seguramente, esta “juste mesure n'est certainement pas une moyenne abstraite qu'on pourrait définir pour tous: elle dépend, comme on l'a dit, de l'histoire et de la complexion de chaque individualité", ${ }^{11}$ daí ser o papel do intérprete não procurar conceitos na abstração, mas construir a resposta a partir da condição concreta daquele que compreende. ${ }^{62} \mathrm{O}$ valor da quantificação suplanta a qualidade e não passa de uma vã tentativa de superação do caos hermenêutico instalado na jurisdição que em muito contribui para o aumento das demandas e dos recursos. A súmula vinculante, como refere Lenio Streck ${ }^{63}$ não passa de uma "adaptação darwiniana" do sistema jurídico que culmina em decisóes inconstitucionais porque destituídas de fundamentação (art. 93, IX, da CF), uma vez que, invariavelmente, a aplicação do verbete da súmula não é contextualizado em uma decisão justificada.

Quanto à independência (b), o Banco Mundial a divide em três espécies. A decisória ou funcional (1), ou seja, entende que as decisões devem ser proferidas de acordo com a lei e não de acordo com fatores políticos. A independência interna (2) relaciona-se àquela ao próprio Poder Judiciário no que diz com suas divisões internas e seus diferentes graus hierárquicos e; independência pessoal (3), do homem juiz em relação aos inúmeros fatores que podem macular sua imparcialidade. No entanto, como pode ser visto do teor do artigo 93, II, c, da Constituição Federal, a promoção dos juízes, por merecimento, dependerá “[...] da produtividade e da presteza no exercício da jurisdição [...]”, o que, à evidência constitui-se em fator de fragilização da própria independência e de fortalecimento da preocupação preponderante com a quantificação e o fluxo.

Ao inverterem a lógica do processo e da jurisdição - da qualidade para a quantidade- o Banco Mundial e os responsáveis pelas reformas processuais no Brasil, estabelecem como valor fundamental a celeridade, pois as expressões - produtividade e presteza- seguramente indicam que a eficiência -um valor neoliberal-só estará presente se o processo iniciar e terminar "em tempo razoável" como refere o inciso LXXVIII do art. $5^{\circ}$ da Constituição Federal. Os estudos de direito comparado mostram ser equivocada tal hermenêutica, uma vez ser a jurisprudência do Tribunal de Strasburgo orientada no sentido de que no processo seja respeitado o tempo-espaço necessário para a implementação dos princípios processuais constitucionais. ${ }^{64}$

${ }^{61}$ Garapon, Antoine. Allard, Julie. Gros, Frédéric. Las vertus du juge, p. 153.

${ }^{62}$ STRECK, Lenio. O que é isto - decido conforme minha consciência?, p. 37.

${ }^{63}$ Streck, Lenio. Novo Código de Processo Penal. O problema dos sincretismos de sistemas inquisitorial e acusatório, p. 127.

${ }^{64}$ Nunes, Dierle José Coelho. Processo jurisdicional democrático, pp. 153-154. 
Teria a celeridade a "qualquer preço" sido inserida na dimensão de dignidade humana? Parece que não. O inciso LXXVIII do art. $5^{\circ}$ da Constituição Federal se inegavelmente é fruto do fenômeno inescapável da constitucionalização do direito internacional, ${ }^{65}$ não autoriza uma hermenêutica contrária à própria concepção de devido processo legal que tome o tempo razoável como um princípio que não autoriza a negação de garantias processuais que formam o "bloco de constitucionalidade" ${ }^{66}$ protetivo do processo, como a ampla defesa e o contraditório previstos no artigo $5^{\circ}, \mathrm{LV}$ da Constituição Federal e dos direitos materiais em geral. No limite, pode-se afirmar, dando atualidade ao pensamento de Francesco Carnelutti, ${ }^{67}$ de que "[...] Por desgraça, a justiça, se é segura não é não rápida e se rápida não é segura $[\ldots]$ ”.

Derradeiramente, há que se dizer que a imposição da rapidez implica numa perigosa conseqüência: a rotina. ${ }^{68}$ Por isso, uma justiça em que a celeridade seja convertida em um metavalor transforma-se em vítima dela própria e aumenta o seu grau de patologização. Entretanto, a Meta No $5^{69}$ do Conselho Nacional de Justiça indica um sentido contrário quando põe em pauta a necessidade de implantação de um método de gerenciamento de rotinas em pelo menos $50 \%$ das unidades judiciárias do País. Desse modo, sem que se faça a apologia de um pessimismo redutor, é preciso desconfiar do otimismo excessivo.

No que tange à eficiência (c), a agência internacional interessa-se pela ação do Estado em relação ao mercado, uma vez ser ele, na atualidade, o leito do rio neoliberal, o lugar revelador de algo como que a verdade, logo de veridição, conforme afirmou Foucault. ${ }^{70}$ Nesse sentido, para o Banco Mundial, o Judiciário deve maximizar sua capacidade para resolver demandas. ${ }^{71}$ Em outras palavras,

\footnotetext{
${ }^{65}$ Pois previsto na alínea 1, do art. 8 , da Convenção Interamericana dos Direitos Humanos e artigo $9^{\circ}, \$ 3^{\circ}$ do Pacto Internacional dos Direitos Civis e Políticos de 1966. Disponíveis, respectivamente em: http://www. oas.org/Juridico/spanish/tratados/b-32.html e http://www.interlegis.gov.br/processo_legislativo/copy_of_2 0020319150524/20030616104212/20030616113554/.

${ }^{66}$ Formado pelo que prevê a Constituição; os chamados "direitos implícitos"; pelo jus cogens; pelo direito convencional internacional os direitos humanos e pelo direito internacional consuetudinário. Humberto Nogueira Alcalá. Dignidade de la persona..., p. 603.

${ }^{67}$ Carnelutti, Francesco. Cómo se hace un proceso. Bogotá: Temis, 1994, p. 14.

${ }^{68}$ Crítica nesse sentido é feita por SANTOS, Boaventura de Sousa. Para uma revolução democrática da Justiça. São Paulo: Cortez, 2007, p. 81.

${ }^{69}$ Disponível em: http://www.cnj.jus.br/index.php?option=com_content\&view=article\&id=10350\&Itemi $\mathrm{d}=1125$. Acesso em 02 de junho de 2010 .

${ }^{70}$ Foucault, Michel. Nascimento da biopolítica, p. 45.

${ }^{71}$ Essa perspectiva circunscreve-se no âmbito da Teoria da Análise Econômica do Direito em que, fundamentalmente, a Economia passa a ser entendida como um método aplicável aos mais diversos campos do
} 
deve ser rápido, reduzir custos e aplicar a eqüidade. Essas expectativas devem ser harmonizadas com a exigência de imparcialidade. O Poder Judiciário, como se vê das reformas trazidas pela Emenda Constitucional 45/2004, tem-se aberto à eficiência, pois além da súmula vinculante, da repercussão geral, mostra disso é a chamada súmula impeditiva de recursos, a padronização das práticas e atos por meio da virtualização, entre outros.

A exigência de que os juízes brasileiros participem de cursos de cursos de capacitação em administração judiciária, conforme se verifica do teor da Meta 8 do Conselho Nacional de Justiça se não é um mal em si mesmo, carrega consigo algo mais profundo que é o gerenciamento como expressão imperial da padronização voltado à universalização. E aqui reside o perigo. A prestação jurisdicional tende, dessa maneira, a ser equiparada a qualquer atividade humana voltada à concorrência e à produtividade. Banaliza-se seu sentido, reforça-se o arbítrio uma vez ser a quantificação o metavalor, transformada em enunciado performativo e fragiliza-se a qualidade das decisóes que deve ser objeto de reflexão no âmbito de uma teoria da decisão ainda pendente de construção por parte da doutrina.

Assim, novamente, quando a Constituição Federal no artigo 5º, LVXXVIII prevê a duração razoável do processo e a penalização aos juízes que excederem os prazos legais tal como prevê o art. 93, II, e; a promoção dos juízes a partir da produtividade conforme prevê o art. 93, II, c, quando o sistema como um todo prestigia a simplificação de ritos; estudos sobre agilização processual; iniciativas legislativas como a criação de um novo Código de Processo Civil com possibilidade de criação de incidente de coletivização e visibilidade através dos meios de comunicação, coloca a eficiência como um valor incontestável. ${ }^{72}$ Segundo essa lógica, as deliberações dos juízes no que diz respeito ao cumprimento de seus deveres funcionais e da administração da Justiça ficam sob o olhar do Conselho Nacional de Justiça, órgão do Poder Judiciário a quem cabe fazer o controle da atividade jurisdicional. ${ }^{73}$

A transparência (d), como se pode notar, é uma decorrência das exigências de eficiência. Ligada à responsabilidade dos juízes e à prestação de contas à popu-

conhecimento desde Bentham e Adam Smith. Tal método consiste na escolha racional em um mundo em que os recursos são limitados. Nesse sentido, o Poder Judiciário seria um ator importante para a maximização da riqueza, daí a preocupação com a quantificação, com a redução de demandas e de custos. PosNER, Richard. Economic Analisys of Law. New York: Aspen, 2003.

${ }^{72}$ Garapon, Antoine. Um nouveau modèle de justice: efficacité, acteur stratégique, sécurité. Esprit. Dans la tourmente (I). Aux sources de la crise financière. Nov/2008. Paris, p. 99.

${ }^{73}$ É o órgão administrativo permanente de que fala o Documento 319 S. 
lação, incrementa-se por meio da informatização generalizada dos processos, da comunicação dos atos processuais pela internet, pela atividade da TV Justiça e pela exigência de que anualmente os tribunais superiores forneçam relatórios sobre sua atividade administrativa e jurisdicional. Para o Banco Mundial esse seria um fator de aumento da confiança dos cidadãos no Judiciário como também repercutiria na reputação dos juízes. A Meta 7 do Conselho Nacional de Justiça reforça essa orientação na medida em que promete disponibilizar mensalmente em seu portal a "produtividade" dos juízes brasileiros.

A orientação pelo primado da transparência seguramente visa a atender a um dos três novos critérios da Justiça postos por Antoine Garapon: $:^{74}$ a segurança. Essa passa a representar uma referência na busca pela homogeneização dos processos. Um valor moderno exacerbado por meio do processo.

Nesse sentido, a virtualização do processo ${ }^{75}$ como um todo, como parece estar determinado a ocorrer, contribui para esse controle, muito mais ligado aos fatores de produtividade do que de qualidade. É, assim, tratada como se fosse realmente a solução para os gargalos que emperram a prestação da Jurisdição, a sugerir uma subserviência à razão proléptica ${ }^{76}$ que trata o futuro sem cuidado. E essa visão curta do futuro ${ }^{77}$ é marcada por um tipo de temporalidade precária e efêmera, como enuncia Gilles Lipovetsky, a propósito da pós-modernidade, tão rica de "hipercapitalismo, hiperclasse, hiperterrorismo, hiperindividualismo, hipermercado, hipertexto". ${ }^{78}$ Pergunta o autor: "O que mais não é hiper?"79.

Ora, tal pujança superlativa está a combinar com a virtualização do processo que, se não é um mal em si mesmo, se usada de modo desconectado das preocu-

\footnotetext{
${ }^{74}$ Os outros dois são: a eficiência e a escolha racional do jurisdicionado. In: Um nouveau modèle de justice: efficacité, acteur stratégique, sécurité, p. 2.

${ }^{75}$ Conforme prevê a Lei 11.419/2007.

${ }^{76}$ Saldanha, Jânia Maria Lopes. Da teoria geral do processo à teoria da tradução: um aporte da sociologia das ausências e da sociologia das emergências. In: Didier JR., Fredie; JorDÃo, Eduardo Ferreira. Teoria do Processo - Panorama Doutrinário Mundial. Salvador: Podium, 2007, p. 389-428.

${ }^{77}$ Boaventura de Sousa Santos apresenta essas mesmas críticas à pós-modernidade e às consequências da globalização que denomina de hegemônica. No entanto, é em sua "teoria da tradução" que é possível encontrar-se uma compreensão diferente do futuro quando o autor trata do que denomina sociologia das emergências, diagnosticando que os homens por acharem que tudo é possível, não cuidam do futuro e banalizam as expectativas e reais possibilidades de construí-lo de forma emancipadora. In: SANTOS, Boaventura de Sousa (Org.) Conhecimento prudente para uma vida decente. São Paulo: Cortez, 2004, p. 779-780.
}

${ }^{78}$ Lipovetsky, Giles. Charles, Sébastien. Les temps hypermodernes. Paris: Grasse, 2004, pp. 49-51.

${ }^{79}$ Lipovetsky, Giles. Charles, Sébastien. Les temps hypermodernes, p. 51. 
pações que se deve ter com a qualidade das decisões marcará o início, quem sabe, de um processo pós-humano ${ }^{80}$ que distanciará ainda mais o julgador -e o sentimento constitucional que deve ter- do caso a julgar e selará a inconstitucionalidade de decisóes sem legitimidade, cujo grau maior ou menor se mede: a) pela influência da atuação das partes no conteúdo da decisão ${ }^{81}$ b) pela exigência de que a decisão seja compatível com a Constituição ${ }^{82}$ portanto, fundamentada com base nela e não produto da "vontade" ou da "consciência" de um julgador transformado em "operador" e "aplicador" irresponsável de verbetes que se distanciam da faticidade do caso e aproximam-se da comodidade em aplicar respostas previamente estabelecidas que tomam contornos de discricionariedade..$^{83}$

Se o valor social preponderante no mundo atual afina-se com a utilidade dos resultados das açôes dos atores sociais, então numa perspectiva funcionalista, o Poder Judiciário na condição de um Poder estatal que compõe esse conjunto de atores não está livre de ver sua atuação avaliada pela sociedade. A transparência de suas ações, facilitada pelos arrojados meios de comunicação -nos quais muito o Poder Judiciário tem investido nos últimos anos- nada mais faz do que viabilizar a percepção social dessa utilidade. Porém, não há de perder-se de vista que sob a aparência da transparência enquanto um valor democrático a ser alcançado a qualquer preço, abre-se franca possibilidade da crítica à instituição na intenção deliberada de fragilizá-la enquanto poder estatal. É que se a mídia desempenha uma função pública e contribui para a socialização e o debate, por outro lado, segue a lógica empresarial e do lucro, uma vez estar centrada nas mãos de grandes corporaçôes. ${ }^{84}$ Como lembra Garapon "o político neoliberal coloca as vítimas das instituições contra o Estado institucional”. ${ }^{85}$

\footnotetext{
${ }^{80}$ Fukuyama adverte que se alguns pensam que o mundo pós-humano será muito parecido com o atual ou com o que se espera do atual -livre, próspero, igual, solidário, compassivo-, deve-se ter cuidado, porque o mundo pós-humano poderá ser muito mais competitivo e com maior conflito social. Segundo ele, poderia ser um mundo em que toda a noção de humanidade partilhada teria sido perdida. FuKUYAMA, Francis. $O$ futuro pós-humano. Rio de Janeiro: Rocco, 2003, p. 225.

${ }^{81}$ Do que na atualidade as audiências públicas que ocorrem no âmbito das ações de controle direto da constitucionalidade são os exemplos mais significativos de reinserção da oralidade no processo e de democratização, conforme prevêem as Leis 9868 e 9872 de 1999.

${ }^{82}$ Streck, Lenio. Novo Código de Processo Penal. O problema dos sincretismos de sistemas inquisitorial e acusatório, p. 131.

${ }^{83}$ STRECK, Lenio. O que é isto - decido conforme minha consciência?, p. 42.

${ }^{84}$ SADER, Emir. Os porquês da desordem mundial. Mestres explicam a globalização. Rio de Janeiro: Record, 2005, p. 107.

${ }^{85}$ Garapon, Antoine. Um nouveau modèle de justice: efficacité, acteur stratégique, sécurité, op. cit., p. 5.
} 
Associada a outros valores - previsibilidade, transparência e constância da instituição- a busca da credibilidade (e) do Poder Judiciário não é um anseio da época moderna. Tucídedes e Platão ${ }^{86}$ demonstraram a desconfiança do povo com a Justiça que pode sempre ser vítima dos desvios da democracia. Os séculos se passaram e a credibilidade é vista como fator de estabilidade política e confiabilidade nas instituições do Estado. Entretando, para o Banco Mundial, um Judiciário confiável é aquele que não aplica arbitrariamente as regras, não é imprevisível e nem corrupto. $\mathrm{O}$ problema surge quando a credibilidade vem associada à eficiência da quantificação tão somente.

O combate à corrupcão (f) como valor, altera o perfil do Poder Judicário e o insere no âmbito da chamada judicialização da política, uma vez que a Jurisdição passa a "julgar para cima", isto é, deixa de julgar apenas as classes populares, cujo contato com o Poder Judiciário, especialmente no campo penal, deu-se, amiúde, de forma repressiva, para incriminar e julgar grandes empresários ou membros da classe política. Como refere Boaventura de Sousa Santos, ${ }^{87}$ é nesse ponto que o cenário muda. Esse "julgar para cima”, segundo o autor, por um lado, produz a judicialização da política, uma vez que o combate à corrupção leva a que muitos conflitos sejam julgados pelo Judiciário e, por outro, conduz à politização do Judiciário, tornando-o mais visível e suscetível às intempéries da política.

A protecão à propriedade privada e aos contratos $(\mathrm{g})$ são duas exigências significativas do Banco Mundial. Para esse, os contratos podem ser revistos apenas "eventualmente" para corrigir distorções do mercado. Facilmente compreensível, uma vez que o mercado é o melhor "ambiente" para a satisfação das necessidades individuais, o que deriva seguramente da concepção da liberdade individual como valor supremo da vida em sociedade. Daí o juiz ter de respeitar os contratos e à propriedade privada, valores fundantes da modernidade, lapidados nas teorizações de Hayek em seu "O caminho da servidão" ${ }^{88}$ e Milton Friedman. ${ }^{89}$ Já no que diz respeito à propriedade privada, mantém-se intocável e são evidentes as regras protetivas contra o roubo e atos predatórios. As penas impostas à prática desses delitos correspondem ao valor social atribuído a esses bens.

Dar acessibilidade (h), para o Banco Mundial, não implica em acesso da população à justiça porque diz-se que a dificuldade pode ser mitigada por outras

\footnotetext{
${ }^{86}$ Ost, François. Contar a lei. São Leopoldo: Editora UNISINOS, 2004, p. 170.

${ }^{87}$ Santos, Boaventura de Sousa. Para uma revolução democrática da Justiça. São Paulo: Cortez, 2007, p. 23.

${ }^{88}$ Friedrich, Hayek. O caminho da servidão. Direito, legislação e liberdade: Uma nova formulação dos princípios liberais de justiça e economia política. São Paulo: Visão, 1985.
}

${ }^{89}$ Friedman, Milton. Capitalismo e liberdade. São Paulo: abril, 1984. 
instâncias que competem com o Poder Judiciário, como as de mediação e arbitragem. Evidente aqui, de certo modo, a defesa da privatização das instâncias de solução de demandas. Para o Banco Mundial o acesso pode ser avaliado por vários fatores: 1) tempo para sentenciar; 2) custos diretos e indiretos sofridos pelas partes; 3) conhecimento, compreensão e utilização dos procedimentos.

Finalmente, o Banco toca em ponto crucial: o ensino jurídico (j).$^{90}$ Afirma que o aprimoramento do ensino jurídico é crucial para a reforma do Poder Judiciário. Nesse sentido, recomenda que não só sejam elevados os níveis de exigência para ingresso e graduação, mas que também estágios para estudantes, cursos continuados para advogados e treinamento para os magistrados são áreas fundamentais da reforma. No campo específico da magistratura brasileira, o art. 93, IV, na redação dada pela Emenda Constitucional No 45/2004 estabelece como critério de promoção na carreira a freqüência a cursos de preparação e aperfeiçoamento na carreira.

Nesse quadro, pode-se facilmente depreender que as reformas processuais advindas com o I Pacto Republicano de Estado por um Sistema de Justiça mais acessível, ágil e efetivo ${ }^{91}$ constituíram-se em resposta à busca do valor -neoliberal- eficiência. No ano de 2009 houve a edição de um conjunto de seis novas leis processuais em cumprimento às recomendações desse Pacto. Onze foram os compromissos firmados nesse Pacto: a) Implementação da Reforma Constitucional do Judiciário; b) Reforma do Sistema Recursal e dos Procedimentos; c) Defensoria Pública ${ }^{92}$ e Acesso à Justiça; d) Juizados Especiais e Justiça Itinerante; e) Execução Fiscal; f) Precatórios; g) Graves Violações contra Direitos Humanos; h) Informatização; ${ }^{93}$ i) Produção de Dados e Indicadores Estatísticos; j) Coerência entre Atuação Administrativa e as Orientações Jurisprudenciais já Pacificadas; l) Incentivo à Aplicação das Penas Alternativas.

\footnotetext{
${ }^{90} \mathrm{O}$ ensino jurídico não se trata de uma questão colateral no amplo espectro de crise do Judiciário. Trata-se, em verdade, de um grave problema estrutural sobre o qual pouco tem recaído a atenção dos responsáveis pelas reformas processuais no Brasil. Sobre o tema veja-se: SALDANHA, Jânia Maria Lopes. Do funcionalismo processual da aurora das luzes às mudanças processuais estruturais e metodológicas do crepúsculo das luzes. Constituição, Sistemas sociais e hermenêutica: Anuário do Programa de Pós-Graduação em Direito da Universidade do Vale do Rio dos Sinos, Porto Alegre: Livraria do Advogado, 2008, pp. 113-134.

${ }^{91}$ No âmbito desse I Pacto as novas leis sobre processo civil foram as seguintes: 1) Ano 2005: 2) Ano 2006: 3) Ano 2007: 4) Ano 2008: 5) Finalmente, no ano 2009 foram editadas as seguintes Leis: Lei 11.925/2009 - Autenticação de cópias pelos advogados; Lei 11.965/2009 - participação de defensores públicos em atos extrajudiciais; Lei 11.969/09 -estruturação da Justiça Federal de primeiro grau-; Lei 12.016/09 -Nova Disciplina ao Mandado de segurança individual e regulamenta o MS. Coletivo-; Lei 12.019/09 -regulamenta a convocação de magistrados para instrução de processo de competência originária do STJ e STF-.

${ }^{92}$ As modificações foram introduzidas no sistema pela Lei Complementar № 132 de 7 de outubro de 2009 a respeito da Defensoria Pública da União, com previsões extensivas às dos Estados.

${ }^{93}$ Com referência a esse objetivo foi editada a Lei 11419/2006.
} 
Passados oito anos do Documento Técnico No 319S, o Banco Mundial quase concomitantemente à entrada em vigor da Emenda Constitucional No 45/2004, apresenta o Relatório 32789-BR ${ }^{4}$ intitulado "Fazendo com que a Justiça conte", de 30 de dezembro de 2004. Nesse Relatório, o Banco Mundial muda o rumo de suas recomendaçóes para dizer que talvez o aumento dos valores orçamentários não seja suficiente para debelar a crise do Judiciário. Com base nessa perspectiva de análise, apresenta três alternativas: a) aumentar a eficiência do Judiciário; b) reduzir a ineficiência de certos órgãos extrajudiciais que condicionam as respostas dos juízes; c) empreender esforço para reduzir a própria demanda.

Para o Banco Mundial, obviamente, somente a primeira alternativa caberia ao Poder Judiciário, sendo que as demais dependem de açôes de outros ramos do governo. Refere que essa alternativa é a mais amplamente aceita e se fará sentir nas instâncias do Judiciário que tiverem mais baixa produtividade, por um lado e naquelas que tenham maior demanda, por outro. No que se refere à segunda alternativa o desafio é imenso, pois para o Banco Mundial tocará em importantes interesses de classe. A terceira, de igual forma, é desafiadora e controvertida, pois implica em interferir em interesses nucleares daqueles que se beneficiam com a justiça morosa.

Três outras recomendações são especificamente importantes: a) aprimoramento da coleta e da análise de dados; b) solução de obstáculos imediatos adicionais ao desempenho; c) as inevitáveis decisões políticas.

O II Pacto Republicano de Estado por um sistema de justiça mais acessível, ágil e efetivo ${ }^{95}$ aponta dezessete pontos de reforma ${ }^{96}$. Do conjunto, pode-se perceber

\footnotetext{
${ }^{94}$ Disponível em:http://web.worldbank.org/WBSITE/EXTERNAL/HOMEPORTUGUESE/EXTPAISES/ EXTLACINPOR/BRAZILINPOREXTN/0,menuPK:3817263 - pagePK:141159 piPK:51068153 - theSite PK:3817167,00.html. Acesso em 30 de jul. de 2009.

${ }^{95}$ Lançado pelos chefes dos três Poderes do Estado em 13 de abril de 2009. Disponível em: http://www.stf. jus.br/portal/cms/verNoticiaDetalhe.asp?idConteudo=106058 Acesso em 28.12.2009.

${ }^{96}$ Os pontos elencados no II Pacto são os seguintes: 1- Conclusão da Reforma Constitucional do Poder Judiciário e das normas relativas ao funcionamento do Conselho Nacional de Justiça, em especial das Propostas de Emenda Constitucional No 358, de 2005 e 324, de 2009; 2- Aprimoramento normativo para maior efetividade do pagamento de precatórios pela União, Estados, Distrito Federal e Municípios; 3- Regulamentação do processo e julgamento da representação interventiva perante o Supremo Tribunal Federal; 4- Regulamentação do processo e julgamento da ação direta de inconstitucionalidade por omissão; 5- Normatização da convocação de juízes para instrução de ações penais originárias nos tribunais superiores; 6- Revisão de normas processuais, visando a agilizar e a simplificar o processamento e julgamento das açôes, coibir os atos protelatórios, restringir as hipóteses de reexame necessário e reduzir recursos; 7- Aperfeiçoamento do sistema de execução trabalhista para incorporar aprimoramentos já adotados no processo de execução civil; 8- Aperfeiçoamento do recurso de revista, do recurso ordinário e do procedimento sumaríssimo no processo trabalhista; 9- Instituição de sistema de uniformização de jurisprudência no âmbito dos Juizados Especiais Estaduais, na esteira do sistema Federal; 10- Estruturação das Turmas Recursais dos Juizados Especiais Federais; 11- Revisão da legislação
} 
que se trata de resposta às indicações do Banco Mundial apresentadas no relatório "Fazendo com que a Justiça Conte".

No mesmo sentido, o Projeto denominado Meta II ${ }^{97}$ lançado no ano de 2009 pelo Conselho Nacional de Justiça também expressa a preocupação desse Órgão de controle pela redução do volume de processos e pelo cumprimento do prazo razoável. Outrossim, as metas prioritárias do Conselho Nacional de Justiça para o ano de 2010 dão continuidade ao projeto de redução do volume de demandas represadas e investem pesadamente nas práticas de gestão e qualificação de juízes e servidores nesse sentido.

Finalmente, no dia 06 de junho de 2010 a Comissão de Juristas ${ }^{98}$ nomeada pelo Senado Federal aprovou o relatório final da proposta de novo Código de Processo Civil. No conjunto das inovações do Código que, se aprovado, terá cinco livros, destaca-se o incidente de resolução de ações repetitivas que tomará por base os denominados "processos-piloto", assim denominados pelo Ministro Luiz Fux,

referente à cobrança da dívida ativa da Fazenda Pública, com vistas à racionalização dos procedimentos em âmbito judicial e administrativo; 12- Atualização do Código de Defesa do Consumidor, com o objetivo de conferir eficácia executiva aos acordos e decisões dos PROCON's, quanto aos direitos dos consumidores; 13- Regulamentação da responsabilidade civil do Estado para estabelecer formas de reparação, em especial no âmbito administrativo, de danos provocados pelo Poder Público, bem como as formas de regresso em relação aos seus causadores; 14- Revisão da Lei de Improbidade Administrativa, assegurando maior eficácia na recuperação de ativos, aprimorando a gestão da Administração Pública e prevenindo ações indevidas e malversação de recursos públicos; 15- Criação de colegiado para julgamento em primeiro grau nos casos de crimes de organizaçôes criminosas, visando a trazer garantias adicionais aos magistrados, em razão da periculosidade das organizações e de seus membros; 16- Atualização da Lei Orgânica da Magistratura - LOMAN; 17 - Nova disciplina constitucional para Medidas Provisórias.

${ }^{97}$ Disponível em: http://www.cnj.jus.br/index.php?option=com_content\&view=article\&id=7909\&Item id=963. Acesso em 28 de dez. de 2009. São dez as metas que o CNJ propôs fossem alcançadas a saber: 1Desenvolver e/ou alinhar planejamento estratégico plurianual (mínimo de 05 anos) aos objetivos estratégicos do Poder Judiciário, com aprovação no Tribunal Pleno ou Órgão Especial; 2- Identificar os processos judiciais mais antigos e adotar medidas concretas para o julgamento de todos os distribuídos até 31/12/2005 (em $1^{\circ}, 2^{\circ}$ grau ou tribunais superiores); 3 - Informatizar todas as unidades judiciárias e interligá-las ao respectivo tribunal e à rede mundial de computadores (internet); 4- Informatizar e automatizar a distribuição de todos os processos e recursos; 5- Implantar sistema de gestão eletrônica da execução penal e mecanismo de acompanhamento eletrônico das prisões provisórias; 6-Capacitar o administrador de cada unidade judiciária em gestão de pessoas e de processos de trabalho, para imediata implantação de métodos de gerenciamento de rotinas; 7- Tornar acessíveis as informações processuais nos portais da rede mundial de computadores (internet), com andamento atualizado e conteúdo das decisões de todos os processos, respeitado o segredo de justiça; 8- Cadastrar todos os magistrados como usuários dos sistemas eletrônicos de acesso a informações sobre pessoas e bens e de comunicação de ordens judiciais (Bacenjud, Infojud, Renajud); 9- Implantar núcleo de controle interno; 10- Implantar o processo eletrônico em parcela de suas unidades judiciárias.

${ }^{98}$ Disponível em: http://www.amb.com.br/index.asp?secao=mostranoticia\&mat_id=20803\#. Acesso em 06.06.2010. 
presidente da referida Comissão, bem como a atribuição dada aos advogados de promoverem a comunicação de atos processuais, a eliminação de algumas vias recursais, o estímulo à uniformização do processo eletrônico, entre outros. E em 8 de junho de 2010, ${ }^{99}$ após pequenos ajustes, a versão definitiva do Anteprojeto de Lei foi entregue ao Senado Federal. Como se vê, haverá uma evidente flexibilização da técnica processual em decorrência do já tão criticado aumento dos poderes do juiz. Por outro lado, em nome da celeridade caminha-se para a privatização do processo o que, evidentemente, traduz-se em descompasso com o perfil constitucional, público e garantista de processo previsto na Constituição Federal. Como refere Luigi Ferrajoli, ${ }^{100}$ "o garantismo necessita do constitucionalismo para fazer realidade seu programa ilustrado; o constitucionalismo se alimenta do projeto garantista para condicionar a legitimidade do poder...". No campo do direito processual, portanto, trata-se de reconhecer que o processo desse cariz deve confirmar o constitucionalismo para fazer realidade os valores constitucionais e as garantias constitucionais que formam o conjunto do direito processual constitucional.

\section{COnSideraçōes Finais}

Sob o ponto de vista da função não há dúvida de que as reformas buscam favorecer a gestão judiciária, a racionalidade do sistema por meio de padrōes de funcionalidade e de comportamentos. Contudo, há uma total ausência de reflexão sobre a repercussão da estandardização e uniformização de práticas sobre a qualidade das decisões. Não são perceptíveis mudanças estruturais, como no que se refere ao perfil individualista, repressivo, voltado à busca das certezas e da segurança, que tem marcado o direito processual no Brasil. Talvez o percurso deva ser mudado para que se reconheça a fragilidade das propostas de cariz neoliberal para a jurisdição quando uma possível saída pode estar na sua democratização, o que não se relaciona à função e sim à sua estrutura.

Embora se devam reconhecer os esforços meritórios para que a jurisdição seja comprometida com as demandas da população, o que se vê das propostas dos dois Pactos Republicanos, do Projeto Meta II e das Metas para 2010 do Conselho Nacional de Justiça, bem como de alguns pontos da reforma que compóe o projeto do novo CPC, o que se vê, sobretudo no Projeto Meta II e que aqui se ousa denominar "Decálogo cibernético", é a preocupação apenas e tão somente com a quantificação e a informatização. Visualiza-se, desse modo, a feição pósmoderna do direito processual, na sua expressão hipermoderna, porque as reformas

${ }^{99}$ Disponível em: http://www.senado.gov.br/agencia/default.aspx?mob=0. Acesso em 08.06.2010.

${ }^{100}$ Garantismo. Uma discusión sobre derecho y democracia. Madrid: Editorial Trotta, 2009, p. 16. 
reforçam elementos modernos nascidos juntamente com o direito processual no Século XIX.

Nesse novo modelo de Justiça que se anuncia, a aplicação do direito é vista do exterior, ou seja, do ponto de vista dos consumidores. Trata-se a Jurisdição de apenas mais um dos tantos serviços que devem orientar-se pelas "boas práticas" neoliberais, reduzida às vantagens ou desvantagens comparativas.

Entretanto, a Constituição Federal sinaliza para outra direção, qual seja, a de um processo como garantia, informado e orientado por princípios e que exige fundamentação das decisões como resultado da comparticipação. É desse processo que se espera mudanças estruturais de abertura e democratização. Em verdade, numa democracia, o direito processual deve refletir os valores constitucionais, como o respeito às cláusulas do devido processo legal, do acesso à justiça, do contraditório, ampla defesa e fundamentação, o que só é possível tendo-se presente a noção de integridade, como lembra Dworkin. ${ }^{101}$ Assim, no contraponto, o processo pode fazer-se antimoderno. $\mathrm{O}$ tratamento dessa questão, entretanto, fica reservado a outro espaço.

\section{REFERÊNCIAS}

Adorno, Theodor. Horkheimer, Max. Dialética do esclarecimento. Fragmentos filosóficos. Rio de Janeiro: Zahar, 1985.

Anderson, Perry. As origens da pós-modernidade. Rio de Janeiro: Zahar, 1999.

ANDrews, Neil. O Moderno Processo Civil. Formas judiciais alternativas de resolução de conflitos na Inglaterra. São Paulo: RT, 2009.

ARENDT, Hannah. Eichmann em Jerusalém: um relato sobre a banalidade do mal. São Paulo: Diagrama \& Texto, 1983.

Aschter, François. Diário de um hipermoderno. Madrid: Alianza Editorial, 2009.

Baptista Da Silva, Ovídio Araújo. A Justiça da lei e a justiça do caso http://www. baptistadasilva.com.br/artigos008.htm. Acesso em 27 dezembro de 2009.

. Da função à estrutura. Constituição, Sistemas Sociais e Hermenêutica. Anuário 2008. Programa de Pós-Graduação em Direito UNISINOS. Porto Alegre: Livraria do Advogado, 2008. . Epistemologia das ciências culturais. Porto Alegre: Verbo Jurídico, 2009.

\footnotetext{
${ }^{101}$ DWORKIN, Ronald. Igualdad, democracia y constitución: nosotros, el pueblo, em los tribunales. In: CARbonell, Miguel. Jaramillo, Leonardo García (Editores). El Canon Neoconstitucional. Bogotá: Universidad Externado, 2010, p. 140-141.
} 
. Jurisdição e execução na tradição romano-canônica. São Paulo: RT, 1997. BaUman, Zygmunt. Ética pós-moderna. Rio de Janeiro: Zahar, 2006. . O mal-estar da pós-modernidade. Rio de Janeiro: Zahar, 1997. - Vida para o consumo. A transformação das pessoas em mercadoria. Rio da Janeiro: Zahar, 2008.

Boltanski, Luc. Chiapello, Ève. O novo espírito do capitalismo. São Paulo: Martins Fontes, 2009.

Calmon de Passos, J.J. Instrumentalidade do Processo e devido processo legal. Revista Sintese de Direito Civil e de Direito Processual Civil. n. 7. Porto Alegre: Síntese, 2000.

Calvo Garcia, Manuel. Transformações do Estado e do Direito. Porto Alegre: Dom Quixote, 2007.

CAmBI, Eduardo. Neoconstitucionalismo e neoprocessualismo. Direitos fundamentais, políticas públicas e protagonismo judiciário. São Paulo: RT, 2009.

CANTOR, Ernesto Rey. El derecho procesal constitucional. Um nuevo concepto. Bogotá: Ediciones Doutrina y Ley Ltda., 2010.

Cantor, Ernesto Rey. Control de Convencionalidad de Las Leyes y Derechos Humanos. México: Editorial Porrúa, 2008.

Carnelutti, Francesco. Cómo se hace un proceso. Bogotá: Temis, 1994, p. 14.

Castanheira Neves, A. O direito hoje e com que sentido? O problema actual da autonomia do Direito. Lisboa: Piaget, 2002.

. O direito interrogado pelo tempo presente na perspectiva do futuro. Boletim da Faculdade de Direito. Coimbra: Coimbra, 2007.

Cattoni de Oliveira, Marcelo Andrade. Processo e jurisdição constitucional. In: . (Coord.) Jurisdição e hermenêutica constitucional no Estado democrático de Direito. Belo Horizonte: Mandamentos, 2004.

Chevallier, Jacques. O Estado pós-moderno. Belo Horizonte: Editora Fórum, 2009.

Cномкку, Naom. El beneficio es lo que cuenta. Neolilberalismo y ordem global. Barcelona: Crítica, 1999.

Coutinho, Jacinho Nelson Miranda. Efetividade do processo penal e golpe de cena: Um problema às reformas processuais. In: Wanderlich, Alexandre (Org.). Escritos de direito e processo penal em homenagem ao professor Paulo Cláudio Tovo. Rio de janeiro: Lúmen Júris, 2001.

DAMASKA, Mirjan. Las caras de la justicia y el poder del Estado. Análisis comparado del proceso legal. Santiago: Editorial Jurídica de Chile, 2000. 
Dinamarco, Cândido Rangel. Instrumentalidade do processo. São Paulo: Malheiros, 2005.

DwORKIN, Ronald. Igualdad, democracia y constitución: nosotros, el pueblo, em los tribunales. In: Carbonell, Miguel. Jaramillo, Leonardo García (Editores). El Canon Neoconstitucional. Bogotá: Universidad Externado, 2010.

Eagleton, Terry. As ilusões do pós-modernismo. Rio de Janeiro: Zahar, 1998.

FÉHer, Ferenc. Heller, Agnes. A condição política pós-moderna. Rio de Janeiro: Civilização Brasileira, 1998.

Ferrajoli, Luigi. Los fundamentos de los derechos fundamentales. In: FerraJOLI, Luigi. Los fundamentos de los derechos fundamentales. Madrid: Editorial Trotta, 2007.

. Garantismo. Uma discusión sobre derecho y democracia. Madrid: Editorial Trotta, 2009.

FISs, Owen. Um novo processo civil. Estudos norte-americanos sobre jurisdição, constituição e sociedade. São Paulo: RT, 2004.

Foessel, Michael. Néolibéralisme versus libéralisme? Esprit. Dans la tourmente (I). Aux sources de la crise financière. Nov/2008. Paris.

Foucault, M. Nascimento da biopolítica. São Paulo: Martins Fontes, 2008.

Friedman, Milton. Capitalismo e liberdade. São Paulo: abril, 1984.

FRIEDRICH, Hayek. O caminho da servidão. Direito, legislação e liberdade: Uma nova formulação dos princípios liberais de justiça e economia política. São Paulo: Visão, 1985.

Fromm, Erich. Psicoanálisis de la sociedade contenporánea. México: Fondo de Cultura Econômica, 2006.

FukUYama, Francis. O futuro pós-humano. Rio de Janeiro: Rocco, 2003.

GadAmer, Hans-Georg. Acotaciones hermenêuticas. Madrid: Trotta, 2002. - O problema da consciência histórica. Rio de Janeiro: FGV, 2003.

Gaiger, Luiz Inácio. Eficiência. Cattani A. D.; Laville. J.-L.; Gaiger, L.I.; Hespanha, P. (Coord.). Dicionário Internacional da Outra Economia. Coimbra: Almedina, 2009.

Garapon, Antoine; Alard Julie. Os juizes na mundialização. A nova revolução do Direito. Lisboa: Piaget.

- O guardador de promessas. Justiça e democracia. Lisboa: Piaget.

. Un nouveau modèle de justice: efficacité, acteur stratégique, sécurité. Esprit. Dans la tourmente (I). Aux sources de la crise financière. Nov/2008. Paris. . Allard, Julie; Gros, Frédéric. Les vertus du juge. Paris: Dalloz, 2008. 
García Márquez, Gabriel. Crônica de uma morte anunciada. Rio de Janeiro: Record, 2009.

Giddens, Anthony. Beck, Ulrich. Lash, Scott. Modernização reflexiva. São Paulo: Unesp, 1997.

Haberle, Peter. Hermenêutica constitucional. A sociedade aberta dos intérpretes da Constituição: contribuição para a interpretação pluralista e procedimental da Constituiçãa. Porto Alegre: Safe, 1997.

Harver, David. Condição pós-moderna. São Paulo: Loyola, 2009.

- O neoliberalismo. História e implicações. São Paulo: Edições Loyola, 2008.

Heller, Agnes. FéHer, Ferenc. Políticas de la posmodernidad. Ensayos de la crítica cultural. Barcelona: Ediciones Península, 1989.

Kaufmann, Arthur. Filosofia do Direito. Lisboa: Calouste Gulbenkian, 2007.

Lipovetsky, Gilles. Charles, Sébastien. Les temps hypermodernes. Paris: Grasse, 2004.

LOPES JÚNIOR, Auri. Justiça negociada. Utilitarismo processual e eficiência antigarantista. In: Diálogos sobre a justiça dialogal. Teses e antíteses sobre os processos de informalização e privatização da justiça penal. Rio de Janeiro: Lúmen Júris, 2002.

Lyotard, Jean-François. A condição pós-moderna. São Paulo: José Olympio, 2008.

Macpherson, C. B. La théorie politique de l'individualisme possessif. Paris: Gallimard, 2004.

Nogueira A., Humberto. Dignidade de la persona, derechos fundamentales y bloque constitucional de derechos: Uma aproximação desde Chile e América Latina. In: Velandia Canosa, Eduardo Andres. (Coord.). Derecho Procesal Constitucional. Colombia: Agencia Imperial, 2010.

Nunes, Dierle José Coelho. Processo Jurisdicional democrático. Uma análise crítica das reformas processuais. Curitiba: Juruá, 2009.

Ost, François. Contar a lei. São Leopoldo: Editora UNISINOS, 2004.

PICARDI, Nicola. Jurisdição e processo. Rio de Janeiro: Forense, 2008.

Posner, Richard. Economic Analisys of Law. New York: Aspen, 2003.

. Para além do direito. São Paulo: Martins Fontes, 2009.

RORTY, Richard. Objetivismo, relativismo e verdade. Escritos filosóficos I. Rio de Janeiro: Relume Dumará, 2002. 
Rosa, Alexandre Morais da. Aroso Linhares, José Manuel. Diálogos com a Law \& Economics. Rio de Janeiro: Lúmen Júris, 2009.

Rosanvallon, Pierre. La contre-democracie. La politique à l'age de la défiance. Paris : Seuil, 2006. pp. 232-233.

SADER, Emir. Os porquês da desordem mundial. Mestres explicam a globalização. Rio de Janeiro: Record, 2005.

Saldanha, Jânia Maria Lopes. Espindola, Angela Araújo da Silveira. A jurisdição constitucional e o caso da ADI 3510: Do modelo individualista -e liberal-ao modelo coletivo -e democrático- de processo. In: Repro. 154, ano 32, dez. 2007.

. Da teoria geral do processo à teoria da tradução: um aporte da sociologia das ausências e da sociologia das emergências. In: Didier Jr., Fredie; JorDÃo, Eduardo Ferreira. Teoria do Processo - Panorama Doutrinário Mundial. Salvador: Podium, 2007.

. Da teoria geral do processo à teoria da tradução. Um aporte da sociologia das ausências e das emergências. In: DiDIER Jr., Fredie. Teoria do Processo Panorama doutrinário mundial. Salvador: Podium, 2007.

. Do funcionalismo processual da aurora das luzes às mudanças processuais estruturais e metodológicas do crepúsculo das luzes. Constituição, Sistemas Sociais e Hermenêutica: Anuário do Programa de Pós-Graduação em Direito da Universidade do Vale do Rio dos Sinos, Porto Alegre: Livraria do Advogado, 2008.

Santos, Boaventura de Sousa (Org.) Conhecimento prudente para uma vida decente. São Paulo: Cortez, 2004.

- (Org.). A globalização e as ciências sociais. São Paulo: Cortez Editora, 2002.

. Para uma revolução democrática da Justiça. São Paulo: Cortez, 2007.

Smith, Adam. A riqueza das Nações. Vol. I. São Paulo: Martins Fontes, 2003.

Streck, Lenio Luiz. Novo Código de Processo Penal. O problema dos sincretismos de sistemas (inquisitorial e acusatório). Revista de Informação Legislativa. Brasília. Ano 46. No 183. jul/set - 2009.

. Verdade e Consenso: Constituição, hermenêutica e teorias discursivas da possibilidade à necessidade de respostas corretas em Direito. Rio de Janeiro: Lumen Juris, 2009.

. O que é isto - decido conforme minha consciência? Porto Alegre: Livraria do Advogado, 2010. 
Theodoro Júnior, Humberto. Nunes, Dierla José Coelho. Uma dimensão que urge reconhecer no contraditório no direito brasileiro: sua aplicação como garantia de influência, de não surpresa e de aproveitamento da atividade processual. In: Revista de Processo. V. 168. São Paulo: RT, fev./2009, pp. 107-141.

VAтtimo, Giovanni. O fim da modernidade. Niilismo e hermenêutica na cultura pós-moderna. São Paulo: Martins Fontes, 2002.

Verdú, Pablo Lucas. Teoría de la constitución como ciencia cultural. Madrid: Dikinson, 1998.

ŽIžEK, Slavoj. A visão em paralaxe. São Paulo: Boitempo, 2008. 